\title{
James Malcolm Swaine \\ 1878-1955
}

Dr. J. M. Swaine, former Director of Science Service, Canada Department of Agriculture, died at his home, 484 Brierwood Avenue, Ottawa, on November eleventh, shortly after his seventy-seventh birthday.

Dr. Swaine was born at Barrington, Nova Scotia, the son of Capt. James Swaine and Sophia Hamilton. He attended school at Yarmouth, Nova Scotia and later the Provincial Normal School at Truro. Subsequently he taught school at South Ohio, Nova Scotia, and later entered the Nova Scotia Agricultural College. In 1905 he graduated from Cornell University with his B.S.A., to be followed by his Master's.

For two years Dr. Swaine was Assistant in Entomology and Zoology at Cornell. He returned to Canada in 1907 and for the next five years lectured in the same subjects at Macdonald College of McGill University. In 1912, having attained international fame for his research on forest entomology, he was brought to Ottawa to become Officer-in-Charge of the Forest Insect Section of the Division of Entomology. On presentation of his thesis on Canadian Bark Beetles he was awarded his Ph.D. by Cornell University. In 1923 he was appointed Associate Dominion Entomologist.

Dr. Swaine was regarded throughout his lifetime as a scientist of high standing and ability. He was the author of many papers on entomology and other scientific subjects and was honored by being made a member of the Royal Society of Canada.

During the Second World War Dr. Swaine served on the Agriculture Supply Board. For his services he was decorated with the Order of a Companion of the British Empire.

He was a member of the American Association of Applied Science, the Entomological Society of America, the Entomological Society of Ontario, the American Association of Economic Entomologists, and the Quebec Society for the Protection of Plants.

He was a Fellow of the Royal Society of Canada, and a charter member of the Canadian Society of Technical Agriculturists.

Dr. Swaine laid the foundations of forest entomology in Canada during his term of office as Associate Dominion Entomologist. His work on the control of the European spruce sawfly, a pest that, for a time, threatened the entire spruce forests of North America, was one of his greatest contributions.

In 1934 he left the field of forest entomology and became Director of Research for the Department of Agriculture. He held this position until the department's reorganization and his appointment in 1937 to the Directorate of Science Service.

Dr. Swaine's activities were not confined to his official duties. He made friends easily and took a personal interest in his staff and in the life of the community in which he lived. An ardent fisherman, he loved the forest and the outdoors. At home his hobbies were reading, particularly of ancient and prehistory, and drawing in pastels.

In 1905 he was married to Mary Creelman of Truro, Nova Scotia, who celebrated with him their golden wedding anniversary on March twenty-eighth, 1955. Their daughter, Allison, married Dr. I. Timonin, formerly with the Division of Bacteriology in the Department of Agriculture at Ottawa. Dr. and Mrs. Timonin, who have four children, are now residents in Mobile, Alabama. The oldest grandson, Ivan, is a student at Carleton College, Ottawa, and lives with Mrs. Swaine at the family home, 484 Brierwood Avenue. 